\title{
KSZTALCENIE ZAWODOWYCH KOMPETENCJI TLUMACZY TEKSTÓW PRAWNYCH I PRAWNICZYCH W RAMACH STUDIÓW PODYPLOMOWYCH
}

\author{
Justyna SEKULA \\ Uniwersytet Pedagogiczny im. Komisji Edukacji Narodowej w Krakowie \\ Kraków, Polska \\ se.justyna.kula@gmail.com
}

\begin{abstract}
Abstrakt: Artykuł przedstawia wyniki analizy porównawczej ofert studiów podyplomowych pod względem kształcenia zawodowych kompetencji tłumaczy tekstów prawnych i prawniczych organizowanych przez Uniwersytet Warszawski, Katedrę UNESCO do Badań nad Przekładem i Komunikacją Międzykulturową Uniwersytetu Jagiellońskiego, Uniwersytet im. Adama Mickiewicza w Poznaniu, Uniwersytet Wrocławski oraz Uniwersytet Mikołaja Kopernika w Toruniu, zawiera porównanie zakresu kształcenia w ramach ww. studiów oraz określa przydatność doskonalenia zawodowego w postaci studiów podyplomowych w późniejszej praktyce zawodowej.
\end{abstract}

Słowa klucze: przekład, tekst prawniczy, kształcenie, studia podyplomowe, kompetencje tłumacza.

\section{TRAINING PROFESSIONAL COMPETENCES OF LEGAL TEXT TRANSLATORS IN THE FRAMEWORK OF POSTGRADUATE STUDIES}

\begin{abstract}
The article presents the results of a comparative analysis of postgraduate studies in terms of training professional competences of the legal text translators, which are organized by the University of Warsaw, UNESCO - Chair for Translation Studies and Intercultural Communication of the Jagiellonian University, Adam Mickiewicz University in Poznań, the University of Wrocław as well as Nicolaus Copernicus University in Torun. It includes a comparison of range of education within the above-mentioned studies and determines the usefulness of professional development in the form of the postgraduate studies in the later work experience.
\end{abstract}

Key words: a translation, a legal text, development, postgraduate studies, the competence of a translator. 
Justyna Sekula: Ksztatcenie zawodowych kompetencji ...

\section{Wstęp}

Przekład jak również dydaktyka przekładu prawniczego cieszą się w Polsce coraz większym zainteresowaniem, na co wskazuje ukazywanie się na polskim rynku wydawniczym nowych publikacji z tego zakresu, a także powstawanie blogów internetowych poświęconych tej tematyce, jak ten prowadzony przez Renatę Świgońską. Zainteresowanie tłumaczeniem prawniczym, chęć kształcenia się w tym zakresie adeptów zawodu, a także czynnych zawodowo tłumaczy skutkuje wzrostem liczby ofert doskonalenia zawodowego w postaci kursów i studiów podyplomowych. Osoby zainteresowane ww. ofertami posiadają szerokie możliwości zdobywania wiedzy i kształcenia kompetencji zawodowych - od dostępnej aktualnej literatury z tego zakresu, po bogate oferty edukacyjne.

Dostępność źródeł wiedzy i form dokształcania jest bez wątpienia cennym elementem w procesie zdobywania wiedzy przekładoznawczej, ale może także przysparzać wielu dylematów osobom stojącym przed wyborem konkretnej oferty. Dydaktycy przekładu prawnego i prawniczego, którzy współtworzą programy studiów podyplomowych, nieustannie ulepszają poszczególne cykle kształcenia oraz zakres i sposób kształconych w ramach tych cykli kompetencji. Wybór najefektywniejszej formy dokształcania nie jest zatem łatwy.

Jakie możliwości kształcenia kompetencji zawodowych w zakresie tłumaczeń prawnych i prawniczych w ramach studiów podyplomowych oferują nam Uniwersytet Warszawski, Katedra UNESCO do Badań nad Przekładem i Komunikacją Międzykulturową UJ, Uniwersytet im. Adama Mickiewicza w Poznaniu, Uniwersytet Wrocławski oraz Uniwersytet Mikołaja Kopernika w Toruniu, jakie kompetencje zawodowe kształcone są w ramach studiów podyplomowych prowadzonych przez ww. uczelnie, która $\mathrm{z}$ ofert wydaje się być tą najefektywniejszą oraz jaki jest stopień przydatności kształconych w czasie studiów podyplomowych kompetencji zawodowych w późniejszej praktyce zawodowej - sformułowanie rzetelnych odpowiedzi na powyższe pytania stanowiło cel przeprowadzonej analizy ofert studiów podyplomowych oraz badania ankietowego.

\section{Kompetencja thumaczeniowa}

Przed rozpoczęciem analizy przybliżyć należy samo pojęcie kompetencji tłumaczeniowej, której kształcenie jest nadrzędnym celem zajęć prowadzonych 
w ramach rzeczonych studiów. Czym jest kompetencja thumaczeniowa i w jakim stopniu jest ona definiowalna? Jakie kompetencje powinien posiadać thumacz? Badania nad kompetencją thumaczeniową prowadzone są przez badaczy z takich dziedzin nauki jak językoznawstwo, psychologia, neurologia czy kognitywizm. Zróżnicowanie dziedzin podejmujących się badań nad tym zagadnieniem skutkuje różnorodnością definicji kompetencji tłumaczeniowej spotykanych we współczesnej literaturze fachowej.

Istotnym modelem dotyczącym kompetencji tłumaczeniowej jest model grupy badawczej PACTE (PACTE 2008, w: Dybiec-Gajer 2013: 81-83). Grupa ta definiuje kompetencję tłumaczeniową jako system wiedzy, która wymagana jest do thumaczenia. System ten opiera się na czterech założeniach: jest to wiedza ekspercka, proceduralna (tzn. magazynowana w postaci strategii i procedur), wynika z wzajemnego oddziaływania powiązanych ze sobą subkompetencji, których oddziaływanie integruje najważniejsza z nich, tj. strategiczność działania tłumacza. Subkompetencję strategiczną rozumieć należy jako wiedzę gwarantującą skuteczność procesu tłumaczeniowego, służącą rozwiązywaniu napotkanych problemów thumaczeniowych. Kontroluje ona proces thumaczeniowy oraz aktywuje połączenia między innymi subkompetencjami. Według modelu grupy PACTE w skład kompetencji tłumaczeniowej wchodzą (prócz wymienionej kompetencji strategicznej) cztery subkompetencje: bilingwalna (wiedza potrzebna do komunikowania się w dwóch językach), instrumentalna (wiedza $\mathrm{z}$ zakresu nowoczesnych technologii oraz narzędzi wspierających pracę thumacza), wiedza o thumaczeniu (wiedza o thumaczeniu i zawodzie thumacza) oraz pozajęzykowa (wiedza ogólna, tzw. wiedza o świecie oraz wiedza specjalistyczna). Elementem scalającym ww. kompetencje w modelu PACTE są indywidualne uwarunkowania poznawcze (pamięć, percepcja, uwaga i emocje) i nastawienie thumacza (ciekawość intelektualna, wytrwałość, dyscyplina), które definiowane są jako komponenty psychofizjologiczne.

Interesującą definicję kompetencji tłumaczeniowej zorientowaną dydaktycznie przedstawia Dorothy Kelly (Kelly 2005, w: KościałkowskaOkońska 2013: 143-144). Według niej kompetencja tłumaczeniowa rozumiana jest jako makrokompetencja na którą składają się wiedza, rożne umiejętności, a także podejście do wykonywanego zadania tłumaczeniowego, tak więc cechy związane $\mathrm{z}$ przekładem jako czynnością, która wykonywana jest przez ekspertów. Makrokompetencja tłumaczeniowa składa się według Kelly z następujących składników: komunikacyjnych i tekstowych (umiejętność rozumienia i analizowania tekstów z różnych dziedzin; tworzenia różnych typów tekstów; znajomość różnych cech i konwencji charakterystycznych dla różnych typów tekstów), kulturowych (znajomość aspektów kulturowych kultury 


\section{Justyna Sekuła: Ksztatcenie zawodowych kompetencji ...}

wyjściowej i docelowej), tematycznych (znajomość konkretnych dziedzin), instrumentalnych, psychofizjologicznych, interpersonalnych (umiejętność współpracy ze specjalistami dziedzinowymi) i strategicznych. Wszystkie z wymienionych składników są ze sobą powiązane, a ich rozwój ma wpływ na kształtowanie kompetencji tłumaczeniowej.

Don Kiraly (Kiraly 2000: 13) wprowadza natomiast w swoim modelu podział na kompetencję tlumaczeniowa oraz kompetencję tłumacza. Kompetencja tłumaczeniowa rozumiana jest jako umiejętność wykonywania dobrych jakościowo thumaczeń. Kompetencja thumacza dotyczy natomiast funkcjonowania thumacza w otoczeniu biznesowym, tzn. reklamowaniu swoich usług, sporządzaniu ich wyceny, współpracy z ekspertami dziedzinowymi itd. Kompetencja thumaczeniowa (według europejskiej normy dotyczącej świadczenia usług tłumaczeniowych PN-EN 15038) dotyczy umiejętności tworzenia thumaczeń stosownie do norm rynkowych oraz specyfikacji klienta. Wyszczególnione w normie kompetencje (translatorska, językowa i tekstowa, poszukiwania i przetwarzania informacji, kulturowa oraz kompetencje w zakresie technologii informacyjnej) są niezbędne w procesie tworzenia thumaczeń odpowiadających wymaganiom rynkowym, dlatego mogą być rozumiane jako kompetencje tłumaczeniowe, o czym pisze także Biel ${ }^{1}$.

Badaniem kompetencji tłumaczy tekstów prawniczych zajmuje się także Kubacki (Kubacki w: Małgorzewicz, Bartoszewicz 2013: 69-83). Porównuje on stanowiska badawcze dotyczące kompetencji tłumaczy polskich i niemieckich lingwistów. Według Kubackiego tłumacza powinny cechować nie tylko wysokie kompetencje językowe. Jego praca związana jest z wymiarem sprawiedliwości, dlatego powinien on posiadać kwalifikacje fachowe, a także wiedzę prawniczą. Tylko w ten sposób może on spełniać wymagania stawiane mu przez sąd, prokuraturę czy policję.

Schulz (Schulz w: Małgorzewicz, Bartoszewicz 2013: 131-134) mówiąc o kompetencjach tłumaczy odwołuje się do kompetencji wymienionych przez organizację Transforum, zrzeszającą m.in. szkoły wyższe kształcące tłumaczy, organizacje zawodowe - teoretyków i praktyków przekładoznawstwa. Na konferencji, która odbyła się w 2013 roku w Leverkusen, jako kluczowe kompetencje thumaczy wymienione zostały kompetencje: językowa, fachowa, poszukiwania informacji, kulturowa, tekstowa oraz kompetencje translatorska i ekonomiczna. Wyszczególnione kompetencje są istotnym źródłem informacji

\footnotetext{
${ }^{1}$ zob. Biel, Łucja. 2011. Kompetencja w zakresie świadczenia usług thumaczeniowych a uczenie się przez projekt, [w:] Kompetencje tłumacza. Tom dedykowany Profesor dr hab. Elżbiecie Tabakowskiej, M. Piotrowska i inni (red.), s. 97-99.
} 
dla instytucji kształcących thumaczy, ponieważ odpowiadają wymaganiom stawianym zawodowym tłumaczom przez przyszłych pracodawców.

Kompetencje zawarte $\mathrm{w}$ europejskiej normie dotyczącej świadczenia usług tłumaczeniowych PN-EN 15038 stanowią istotny punkt odniesienia przeprowadzonego badania ankietowego. Według normy, od zawodowych tłumaczy wymagane jest posiadanie kompetencji (PN-EN 15038: 2006, w: Dybiec-Gajer 2013: 61): translatorskiej (umiejętność tłumaczenia tekstów na wymaganym poziomie, zgodnie $\mathrm{z}$ wymaganiami klienta $\mathrm{i}$ specyfikacją tłumaczeniową; zdolność analizy problemów dotyczących zrozumienia i tworzenia tekstu; umiejętność uzasadniania wyników), językowej i tekstowej (zrozumienie tekstu w języku wyjściowym i umiejętność stworzenia tekstu w języku docelowym; znajomość konwencji tworzenia różnych typów tekstów w odniesieniu do tekstów ogólnych i specjalistycznych), poszukiwania i przetwarzania informacji (umiejętność zdobywania dodatkowej wiedzy językowej i specjalistycznej niezbędnej do thumaczenia; umiejętność tworzenia strategii wykorzystywania dostępnych źródeł informacji), kulturowej (umiejętność wykorzystania informacji dotyczących aspektów kulturowych, norm zachowania oraz systemów wartości charakterystycznych dla kultury źródłowej i docelowej) oraz kompetencji w zakresie technologii informacyjnej (umiejętność wykorzystania zasobów technicznych wspierających wykonywanie profesjonalnych thumaczeń).

Przytoczone definicje kompetencji thumaczeniowej oraz zakres wchodzących $\mathrm{w}$ jej skład subkompetencji stanowią jedynie namiastkę badań prowadzonych nad tym zagadnieniem. Jak dotychczas nie sformułowano jednolitej definicji kompetencji tłumaczeniowej, która zawierałaby $\mathrm{w}$ sobie aspekty licznych podejść badawczych i była akceptowalna przez badaczy podejmujących tę tematykę, reprezentujących odmienne stanowiska badawcze. Niejednolitość - prócz definicji samego pojęcia - dotyczy także zakresu subkompetencji wchodzących w skład kompetencji tłumaczeniowej.

\section{Badania Joanny Albin}

W tym miejscu należy odnieść się do wyników badania Albin (Albin 2011, w: Piotrowska 2012: 39-44) przeprowadzonego wśród thumaczy zawodowych języka hiszpańskiego z co najmniej pięcioletnim doświadczeniem zawodowym, którzy wykształcenie zdobyli w Polsce. W przeprowadzonym przez Albin badaniu na pytanie kwestionariuszowe: „Czy uważa Pan/i że na obecnym etapie 
kariery zawodowej jest Pan/i przygotowany/a do zawodu thumacza...?" $20 \%$ ankietowanych odpowiedziała „czasami miewam problemy”, 5\% ankietowanych „zwykle odczuwam brak przygotowania”, 20\% ankietowanych ,znakomicie”, a 55\% z nich ,zadowalająco”. Na kolejne z pytań: „Spośród wymienionych umiejętności, proszę wskazać JEDNA, której BRAK najbardziej utrudnia Panu/i wykonywanie zawodu tlumacza” 30\% thumaczy wskazuje „znajomość konkretnych dziedzin". Badania Albin są istotnym punktem rozważań dotyczących doskonalenia kompetencji zawodowych thumaczy w ramach studiów podyplomowych, dlatego odniosę się do nich również w dalszej części niniejszej pracy.

\section{Analiza porównawcza ofert studiów podyplomowych}

$\mathrm{W}$ celu sformułowania odpowiedzi na pierwsze $\mathrm{z}$ postawionych na początku pytań badawczych - „Jakie kompetencje zawodowe ksztatcone sq $w$ ramach studiów podyplomowych prowadzonych przez ww. uczelnie, która $z$ ofert wydaje się być ta najefektywniejszą?" - przeprowadzona została analiza ofert studiów podyplomowych pod kątem zajęć rozwijających kompetencje zawarte w ww. normie oraz liczby godzin, jakie przeznaczone są na poszczególne bloki teoretyczne i praktyczne zajęć mających rozwijać u studiujących poszczególne kompetencje.

Analiza nie uwzględnia wszystkich bloków zajęć realizowanych w ramach programów poszczególnych studiów. Ukierunkowana została ona na zajęcia kształcące zawodowe kompetencje tłumaczy tekstów prawnych i prawniczych. Przy sporządzaniu poniższego zestawienia nie uwzględnione zostały zatem takie bloki zajęć jak: przekład artystyczny, thumaczenia techniczne czy thumaczenia medyczne i farmaceutyczne. Analizowane programy studiów stanowiące korpus badawczy podane są do informacji publicznej na stronach internetowych uniwersytetów wymienionych w niniejszym artykule. Dla większej przejrzystości wyniki przeprowadzonej analizy porównawczej zestawione zostały w formie tabelarycznej. 


\begin{tabular}{|c|c|c|c|c|c|c|c|c|}
\hline $\begin{array}{c}\text { UNIWER } \\
\text { SYTET }\end{array}$ & $\begin{array}{c}\text { Uniwersyt } \\
\text { et } \\
\text { Warszaws } \\
\text { ki }\end{array}$ & $\begin{array}{c}\text { Katedra } \\
\text { UNESCO } \\
\text { Uniwersyt } \\
\text { etu } \\
\text { Jagiellońs } \\
\text { kiego }\end{array}$ & $\begin{array}{l}\text { UAM w } \\
\text { Poznaniu }\end{array}$ & \multicolumn{2}{|c|}{$\begin{array}{l}\text { UAM w } \\
\text { Poznaniu }\end{array}$} & \multicolumn{2}{|c|}{$\begin{array}{c}\text { Uniwersyt } \\
\text { et } \\
\text { Wroclaws } \\
\text { ki }\end{array}$} & $\begin{array}{l}\text { UMK w } \\
\text { Toruniu }\end{array}$ \\
\hline $\begin{array}{c}\text { Nazwa } \\
\text { prowadzo } \\
\text { nych } \\
\text { studiów }\end{array}$ & $\begin{array}{l}\text { Interdyscy } \\
\text { plinarne } \\
\text { podyplomo } \\
\text { we studium } \\
\text { kształcenia } \\
\text { tłumaczy }\end{array}$ & $\begin{array}{l}\text { Podyplomo } \\
\text { we } \\
\text { studia dla } \\
\text { tłumaczy } \\
\text { tekstów } \\
\text { specjalistyc } \\
\text { znych }\end{array}$ & $\begin{array}{l}\text { Podyplomo } \\
\text { we studia } \\
\text { kształcenia } \\
\text { tłumaczy } \\
\text { specjalistyc } \\
\text { znych }\end{array}$ & \multicolumn{2}{|c|}{$\begin{array}{c}\text { Podyplomo } \\
\text { we studia } \\
\text { dla } \\
\text { kandydató } \\
\text { w na } \\
\text { tłumaczy } \\
\text { przysięgłyc } \\
\text { h }\end{array}$} & \multicolumn{2}{|c|}{$\begin{array}{c}\text { Studia } \\
\text { podyplomo } \\
\text { we } \\
\text { kształcenia } \\
\text { tłumaczy } \\
\text { języka } \\
\text { niemieckie } \\
\text { go }\end{array}$} & $\begin{array}{c}\text { Podyplomo } \\
\text { we studium } \\
\text { kształcenia } \\
\text { tłumaczy }\end{array}$ \\
\hline $\begin{array}{c}\text { Kształceni } \\
\text { e w } \\
\text { ramach } \\
\text { języków } \\
\text { (liczba): }\end{array}$ & 6 & 7 & 1 & \multicolumn{2}{|c|}{7} & & 4 & 6 \\
\hline Języki: & $\begin{array}{l}\text { angielski, } \\
\text { francuski, } \\
\text { hiszpański, } \\
\text { niemiecki, } \\
\text { rosyjski, } \\
\text { włoski }\end{array}$ & $\begin{array}{l}\text { angielski, } \\
\text { francuski, } \\
\text { hiszpański, } \\
\text { niemiecki, } \\
\text { rosyjski, } \\
\text { włoski, } \\
\text { ukraiński }\end{array}$ & angielski & \multicolumn{2}{|c|}{$\begin{array}{l}\text { angielski, } \\
\text { niemiecki, } \\
\text { chiński, } \\
\text { arabski, } \\
\text { francuski, } \\
\text { hiszpański, } \\
\text { rosyjski }\end{array}$} & \multicolumn{2}{|c|}{$\begin{array}{c}\text { francuski, } \\
\text { hiszpański, } \\
\text { włoski, } \\
\text { niemiecki }\end{array}$} & $\begin{array}{l}\text { angielski, } \\
\text { niemiecki, } \\
\text { francuski, } \\
\text { hiszpański, } \\
\text { włoski, } \\
\text { rosyjski }\end{array}$ \\
\hline $\begin{array}{l}\text { Całkowita } \\
\text { liczba } \\
\text { godzin: }\end{array}$ & $360 \mathrm{~h}$ & $284 h$ & $160 \mathrm{~h}$ & \multicolumn{2}{|c|}{$312 \mathrm{~h}$} & \multicolumn{2}{|c|}{$362 \mathrm{~h}$} & $210 \mathrm{~h}$ \\
\hline \multicolumn{9}{|c|}{ Zakres kształconych kompetencji wraz z wymiarem godzinowym } \\
\hline \multicolumn{2}{|c|}{ Translatorska } & 170h & $54 \mathrm{~h}$ & $20 \mathrm{~h}$ & \multicolumn{2}{|c|}{$140 h$} & $120 \mathrm{~h}$ & $100 \mathrm{~h}$ \\
\hline \multicolumn{2}{|c|}{ Językowa i tekstowa } & $20 \mathrm{~h}$ & $46 h$ & $10 \mathrm{~h}$ & \multicolumn{2}{|c|}{$20 \mathrm{~h}$} & $40 \mathrm{~h}$ & $10 \mathrm{~h}$ \\
\hline \multicolumn{2}{|c|}{$\begin{array}{l}\text { Poszukiwania } \\
\text { i przetwarzania } \\
\text { informacji }\end{array}$} & $150 h$ & $8 \mathrm{~h}$ & $36 \mathrm{~h}$ & \multicolumn{2}{|c|}{$134 h$} & $90 \mathrm{~h}$ & $41 \mathrm{~h}$ \\
\hline
\end{tabular}


Justyna Sekula: Ksztatcenie zawodowych kompetencji ...

\begin{tabular}{|c|c|c|c|c|c|c|} 
Kulturowa & $\mathbf{1 0 h}$ & $6 \mathrm{~h}$ & $8 \mathrm{~h}$ & $0 \mathrm{~h}$ & $\mathbf{2 4 h}$ & $3 \mathrm{~h}$ \\
\hline W zakresie IT & $10 \mathrm{~h}$ & $\mathbf{3 6 h}$ & $10 \mathrm{~h}$ & $\mathbf{1 8 h}$ & $16 \mathrm{~h}$ & $6 \mathrm{~h}$ \\
\hline
\end{tabular}

Tabela 1. Tabelaryczne zestawienie kształconych w czasie studiów podyplomowych kompetencji zawodowych wraz $\mathrm{z}$ godzinowym wymiarem zajęć. (Źródło: opracowanie własne)

Powyższe zestawienie pozwala wyodrębnić oferty studiów podyplomowych znacznie wyróżniające się na tle ofert pozostałych uniwersytetów pod względem liczby grup językowych, do których prowadzony jest nabór na studia oraz liczby godzin zajęć teoretycznych i praktycznych przeznaczonych na kształcenie poszczególnych kompetencji. Biorąc pod uwagę liczbę grup językowych, do których prowadzony jest nabór, najkorzystniej wypadają $\mathrm{w}$ tym zestawieniu katedra UNESCO do Badań nad Przekładem i Komunikacją Międzykulturową UJ oraz UAM w Poznaniu, gdzie oferty studiów podyplomowych skierowane są do absolwentów aż siedmiu filologii. Wysokie miejsce zajmuje także Uniwersytet Warszawski, gdzie prowadzony jest nabór do sześciu różnych grup językowych. Pod kątem liczby godzin przeznaczonych na zajęcia kształcące poszczególne kompetencje najkorzystniejszymi są oferty studiów podyplomowych Uniwersytetu Warszawskiego oraz UAM w Poznaniu. Na pięć kształconych wczasie studiów podyplomowych kompetencji zawodowych zawartych w normie europejskiej PN-EN 15038 Uniwersytet Warszawski oraz UAM w Poznaniu przodują w liczbie godzin zajęć rozwijających trzy z nich. W przypadku Uniwersytetu Warszawskiego są to: kompetencja translatorska (170h), badawcza - pozyskiwania i przetwarzania informacji (150h) oraz kulturowa (10h). W przypadku UAM w Poznaniu są to: kompetencja translatorska (140h), badawcza - poszukiwania i przetwarzania informacji (134h) oraz kompetencje w zakresie IT (18h). Uniwersytet Warszawski i UAM w Poznaniu ustępują miejsca pozostałym uniwersytetom jedynie godzinową liczbą zajęć rozwijających dwie spośród pięciu zestawionych kompetencji. W przypadku Uniwersytetu Warszawskiego są to: kompetencja językowa i tekstowa (20h) oraz kompetencje w zakresie IT (10h), UAM w Poznaniu: kompetencja językowa (20h) oraz kulturowa (0h).

Analizując oferty studiów podyplomowych pozostałych uniwersytetów nadmienić należy, że kompetencja translatorska, pozyskiwania i przetwarzania informacji oraz kompetencja językowa są kompetencjami, na których rozwój kładziony jest największy nacisk przez wszystkie $\mathrm{z}$ uniwersytetów, co potwierdzają tabelaryczne zestawienia godzinowe. Nie bez znaczenia są także 
różnice $\mathrm{w}$ ogólnej liczbie godzin zajęć w ramach studiów podyplomowych w odniesieniu do uniwersytetów zajmujących czołowe pozycje w zestawieniu. Różnice pomiędzy poszczególnymi ofertami wynikają również $\mathrm{z}$ mniejszej adekwatności $\mathrm{w}$ nazewnictwie studiów podyplomowych $\mathrm{w}$ odniesieniu do tłumaczeń prawnych i prawniczych. W większości są to studia kształcące tłumaczy tekstów specjalistycznych, czy też ogólnie thumaczy, bez sprecyzowanych w nazewnictwie programu thumaczeń prawnych i prawniczych. W programach tych wyodrębnić można zatem różne zakresy tematyczne tłumaczeń, na rzecz których mniejszy zakres godzinowy zajęć poświęcony jest thumaczeniu prawniczemu.

Kolejnym pytaniem badawczym stanowiącym podstawę przeprowadzonych analiz było określenie stopnia przydatności kształconych w ramach studiów podyplomowych kompetencji zawodowych $\mathrm{w}$ praktyce zawodu tłumacza. W celu udzielenia rzetelnej odpowiedzi na powyższe pytanie przeprowadzone zostało wśród tłumaczy przysięgłych języka niemieckiego badanie ankietowe. Prośba o udział w badaniu skierowana została drogą emailową do dwustu czterdziestu trzech thumaczy przysięgłych, pozytywnie odpowiedziało na nią dwudziestu dwóch tłumaczy ${ }^{2}$. Ankietowani odpowiadali na pytania dotyczące wieku, ukończonych studiów podyplomowych $\mathrm{z}$ zakresu tłumaczeń tekstów specjalistycznych w tym prawnych i prawniczych, rodzaju kompetencji kształconych w trakcie odbytych studiów oraz ich przydatności w praktyce zawodowej oceniając ją $\mathrm{w}$ skali dziesięciopunktowej, gdzie przyznanie dziesięciu punktów oznaczało najwyższy stopień przydatności. Wyniki badania ankietowego przedstawione zostaną etapami w celu uzyskania jak najlepszej ich przejrzystości.

\begin{tabular}{|c|c|c|c|}
\hline \multicolumn{2}{|c|}{ Wiek ankietowanego } & $\begin{array}{c}\text { Biorących udział w formie } \\
\text { doskonalenia zawodowego } \\
\text { w postaci studiów } \\
\text { podyplomowych }\end{array}$ & $\begin{array}{c}\text { Niebiorących udziału w formie } \\
\text { doskonalenia w postaci studiów } \\
\text { podyplomowych }\end{array}$ \\
\hline $\mathbf{2 0 - 3 0}$ & 0 & 0 & 0 \\
\hline $\mathbf{3 0 - 4 0}$ & 11 & 4 & 7 \\
\hline $\mathbf{4 0 - 5 0}$ & 8 & 1 & 7 \\
\hline $\mathbf{5 0 - 7 0}$ & 3 & 0 & $\mathbf{1 7}$ \\
\hline RAZEM & $\mathbf{2 2}$ & $\mathbf{5}$ & \\
\hline
\end{tabular}

\footnotetext{
${ }^{2}$ Składam serdeczne podziękowania tłumaczom, którzy wzięli udział w przeprowadzonym badaniu ankietowym, pozytywnie i życzliwie odpowiadając na skierowaną do nich prośbę.
} 
Tabela 2. Biorący i niebiorący udziału w formie doskonalenia zawodowego w postaci studiów podyplomowych według przynależności do grup wiekowych. (Źródło: opracowanie własne)

Spośród dwudziestu dwóch ankietowanych pięcioro brało udział w formie doskonalenia zawodowego $\mathrm{w}$ postaci studiów podyplomowych. Do grupy tej należą $\mathrm{W}$ większości stosunkowo młodzi tłumacze między trzydziestym a czterdziestym rokiem życia. Jeden $\mathrm{z}$ ankietowanych mieści się $\mathrm{w}$ przedziale wiekowym 40-50 lat. Siedemnastu ankietowanych zadeklarowało niebranie udziału w żadnej z wymienionych form doskonalenia zawodowego. Dziesięciu (na siedemnastu) $\mathrm{z}$ nich to osoby mieszczące się w przedziale wiekowym 40-70 lat, siedmiu natomiast należy do przedziału wiekowego 30-40 lat.

Kolejne $\mathrm{z}$ zestawień przedstawia zakres kompetencji zawodowych kształconych $\mathrm{w}$ czasie studiów podyplomowych przez pięciu ankietowanych, którzy brali udział $\mathrm{w}$ formie doskonalenia $\mathrm{w}$ postaci studiów podyplomowych z zakresu tłumaczeń tekstów specjalistycznych w tym prawnych i prawniczych oraz ocenę stopnia przydatności tych kompetencji w praktyce wykonywania zawodu thumacza wyrażoną przez ankietowanych w skali punktowej.

\begin{tabular}{|c|c|c|}
\hline $\begin{array}{c}\text { Rodzaj kompetencji - } \\
\text { norma PN-EN 15038 }\end{array}$ & $\begin{array}{c}\text { Kompetencje kształcone w czasie } \\
\text { odbytych studiów podyplomowych } \\
\text { (zadeklarowane przez 5 tlumaczy) }\end{array}$ & $\begin{array}{c}\text { Ocena przydatności ksztalconych } \\
\text { kompetencji w praktyce } \\
\text { wykonywania zawodu tlumacza }\end{array}$ \\
\hline Translatorska & 5 & $44 \mathrm{pkt} / 50 \mathrm{pkt}$ \\
\hline Językowa i tekstowa & 5 & $43 \mathrm{pkt} / 50 \mathrm{pkt}$ \\
\hline $\begin{array}{c}\text { Wyszukiwawcza/ } \\
\text { pozyskiwania i } \\
\text { przetwarzania } \\
\text { informacji }\end{array}$ & 4 & $37 \mathrm{pkt} / 50 \mathrm{pkt}$ \\
\hline Kulturowa & 2 & $19 \mathrm{pkt} / 50 \mathrm{pkt}$ \\
\hline $\begin{array}{c}\text { W zakresie technologii } \\
\text { informacyjnej }\end{array}$ & 3 & $21 \mathrm{pkt} / 50 \mathrm{pkt}$ \\
\hline
\end{tabular}

Tabela 3. Zakres kształconych w ramach odbytych studiów podyplomowych kompetencji wraz z punktową oceną ich przydatności w praktyce zawodowej. (Źródło: opracowanie własne)

Wszystkich pięcioro uczestników studiów podyplomowych zadeklarowało obecność w programie odbytych studiów zajęć rozwijających kompetencję translatorską, a także językową i tekstową. Obydwie kompetencje zostały 
ocenione przez tłumaczy jako najbardziej przydatne w praktyce wykonywania zawodu, otrzymując w skali punktowej odpowiednio czterdzieści cztery i czterdzieści trzy na pięćdziesiąt możliwych do zdobycia punktów. Czterech uczestników zadeklarowało rozwijanie w czasie odbytych studiów kompetencji wyszukiwawczej (pozyskiwania i przetwarzania informacji), a jej przydatność w praktyce zawodowej oceniło na trzydzieści siedem na pięćdziesiąt możliwych do przyznania punktów. Kompetencja kulturowa kształcona była w czasie studiów podyplomowych przez jedynie dwóch tłumaczy przysięgłych. Pozostałe programy studiów podyplomowych nie obejmowały zajęć rozwijających tej kompetencji. Kompetencję w zakresie technologii informacyjnej kształciło w czasie odbywanych studiów trzech tłumaczy. Na uwagę zasługuje fakt, że obydwie kompetencje (kulturowa oraz w zakresie IT) ocenione zostały pod względem ich przydatności w praktyce zawodowej na połowę możliwych do zdobycia punktów, aczkolwiek nie były one kształcone u wszystkich ankietowanych poprzez odpowiednie zajęcia objęte programami poszczególnych studiów podyplomowych.

Ostatni aspekt przeprowadzonego badania dotyczy grupy ankietowanych niebiorących udziału w żadnej z wymienionych form doskonalenia zawodowego. Ta część ankietowanych proszona była o udzielenie odpowiedzi na jedynie dwa pytania ankietowe.

\begin{tabular}{|c|c|c|c|c|}
\hline PYTANIE & $\begin{array}{c}\text { TAK/Liczba } \\
\text { ankietowanych }\end{array}$ & $\begin{array}{c}\text { Uwagi } \\
\text { ankietowanych }\end{array}$ & $\begin{array}{c}\text { NIE/Liczba } \\
\text { ankietowanych }\end{array}$ & $\begin{array}{c}\text { Uwagi } \\
\text { ankietowanych }\end{array}$ \\
\hline $\begin{array}{c}\text { Forma } \\
\text { doskonalenia } \\
\text { zawodowego w } \\
\text { postaci studiów } \\
\text { podyplomowych } \\
\text { z zakresu } \\
\text { tłumaczeń } \\
\text { prawniczych } \\
\text { wpłynęłaby } \\
\text { pozytywnie na } \\
\text { moją praktykę } \\
\text { zawodową. }\end{array}$ & 7 & & $\begin{array}{c}7-\text { nie } \\
2 \text { - brak zdania } \\
1 \text { - brak odp. }\end{array}$ & $\begin{array}{c}\text { *Decyzja } \\
\text { uzależniona od } \\
\text { znajomości } \\
\text { programu } \\
\text { studiów } \\
\text { i poziomu } \\
\text { nauczania } \\
\text { *Decyzja } \\
\text { uzależniona od } \\
\text { programu } \\
\text { studiów } \\
\text { i wykładowców. }\end{array}$ \\
\hline $\begin{array}{l}\text { Wzięłabym/ } \\
\text { Wziąłbym udział } \\
\text { w studiach } \\
\text { podyplomowych }\end{array}$ & 8 & $\begin{array}{l}\text { Decyzja } \\
\text { uzależniona od } \\
\text { programu } \\
\text { studiów. }\end{array}$ & $\begin{array}{c}7-\text { nie } \\
1 \text { - brak odp. } \\
1 \text { - brak zdania }\end{array}$ & $\begin{array}{c}\text { *Decyzja } \\
\text { uzależniona od } \\
\text { programu } \\
\text { studiów }\end{array}$ \\
\hline
\end{tabular}


Justyna Sekula: Ksztatcenie zawodowych kompetencji ...

\begin{tabular}{|c|c|c|}
\hline $\begin{array}{l}\text { z zakresu } \\
\text { tłumaczeń } \\
\text { prawniczych } \\
\text { mając taką } \\
\text { możliwość. }\end{array}$ & $\begin{array}{c}\text { Musiałyby być } \\
\text { one na poziomie } \\
\text { zaawansowanym, } \\
\text { gdyż tłumacz } \\
\text { posiada } \\
\text { dwudziestoletnie } \\
\text { doświadczenie } \\
\text { pracy w } \\
\text { zawodzie. }\end{array}$ & $\begin{array}{c}i \text { wyktadowców. } \\
\text { *Sa inne formy } \\
\text { doksztatcania } \\
\text { zawodowego } \\
\text { organizowane } \\
\text { przez } \\
\text { stowarzyszenia, } \\
\text { grupy tlumaczy, } \\
\text { czy organizacje } \\
\text { takie jak TEPIS, } \\
\text { STP, Battyckie } \\
\text { Stowarzyszenie } \\
\text { Ttumaczy, jak } \\
\text { również inne } \\
\text { zagraniczne } \\
\text { organizacje. } \\
\text { *Już nie jestem } \\
\text { zainteresowana. }\end{array}$ \\
\hline
\end{tabular}

Tabela 4. Deklaracje chęci udziału w formie doskonalenia w postaci studiów podyplomowych, ocena pozytywnego wpływu takich studiów na obecną praktykę zawodową. (Źródło: opracowanie własne)

Siedmiu na siedemnastu ankietowanych tłumaczy ocenia, iż odbycie studiów podyplomowych z zakresu tłumaczeń prawniczych wpłynęłoby pozytywnie na ich obecną praktykę zawodową. Wynik ten umacnia znaczenie odbycia tego typu studiów jako istotnej, przede wszystkim przydatnej w praktyce zawodowej formy doskonalenia zawodowego. Siedmioro thumaczy wyraziło opinię, iż taka forma doskonalenia nie miałaby wpływu na ich praktykę zawodową. Wśród komentarzy thumaczy towarzyszących odpowiedziom negatywnym pojawiła się kwestia konieczności znajomości programu studiów, poziomu nauczania, czy też wykładowców. Trzech spośród ankietowanych nie wyraziło swojej opinii. Ośmioro thumaczy wyraziło chęć wzięcia udziału w studiach podyplomowych z zakresu thumaczeń prawniczych, co w dalszym ciągu umacnia przydatność tej formy doskonalenia w praktyce wykonywania zawodu. Siedmioro tłumaczy nie wzięłoby udziału w takiej formie doskonalenia. Powodem wymienionym przez jednego $\mathrm{z}$ ankietowanych jest dostępność innych form czy kursów doskonalących, a także braku takiej potrzeby ze względu na długoletnią praktykę zawodową i biegłość w wykonywaniu tego typu thumaczeń. Dwóch ankietowanych nie udzieliło odpowiedzi na to pytanie ankietowe. 


\section{Wnioski}

Większość z analizowanych ofert studiów podyplomowych odnosi się do kształcenia zawodowych kompetencji tłumaczy tekstów specjalistycznych. W mniejszym stopniu oferty studiów i ich programy zorientowane są na kształcenie w zakresie tłumaczeń prawnych i prawniczych. W praktyce oznacza to, że zajęcia realizowane $\mathrm{w}$ ramach programów studiów są zróżnicowane tematycznie, dotyczą różnych dziedzin fachowych. Brak jest zatem oferty studiów podyplomowych, która w swoim programie podejmowałaby wyłącznie tematykę prawniczą $\mathrm{i}$ w pełni kształciła kompetencje zawodowe niezbędne $\mathrm{u}$ przyszłych tłumaczy tekstów prawnych i prawniczych.

Oferta UAM (studia podyplomowe dla kandydatów na thumaczy przysięgłych) obejmuje znaczącą liczbę zajęć rozwijających zawodowe kompetencje tłumaczy tekstów prawniczych. Korzystna jest także pod tym względem oferta Uniwersytetu Warszawskiego. Największy nacisk kładziony jest przez UAM i UW na rozwój kompetencji translatorskiej, pozyskiwania i przetwarzania informacji oraz kompetencji językowej i tekstowej. Są to trzy kompetencje, które ankietowani thumacze przysięgli określili jako najbardziej przydatne w praktyce wykonywania zawodu.

Obok rozwijania kompetencji translatorskiej jednym z głównych celów studiów podyplomowych powinno być rozwijanie kompetencji wyszukiwawczej (rozwijanie umiejętności zdobywania dodatkowej wiedzy przede wszystkim fachowej, w przypadku wykonywania tłumaczeń prawniczych, wiedzy o systemach prawnych obszaru językowego A i B). Potwierdzenie stanowią badania Albin - thumacze języka hiszpańskiego, wykazujący częste problemy związane $\mathrm{z}$ brakiem znajomości konkretnych dziedzin, a także odpowiedzi ankietowanych tłumaczy przysięgłych języka niemieckiego, którzy wskazali stopień przydatności tej kompetencji w praktyce zawodowej jako jeden z najwyższych.

Cenną uwagą jednego $\mathrm{z}$ thumaczy przysięgłych odpowiadających na pytanie, czy wziąłby udział w studiach podyplomowych z zakresu tłumaczeń prawniczych, było uzależnienie podjęcia takiej decyzji od poziomu studiów podyplomowych. Jako tłumacz z wieloletnim doświadczeniem oczekiwałby on doskonalenia na poziomie zaawansowanym. Może być to przyszłościowy kierunek organizowania studiów podyplomowych. Biorąc pod uwagę liczbę tłumaczy przysięgłych - już praktykujących - chętnych wziąć udział w takiej formie doskonalenia, wartym byłoby stworzenie oferty studiów podyplomowych na poziomie zaawansowanym, skierowanej do czynnej zawodowo grupy thumaczy. 
Justyna Sekula: Ksztatcenie zawodowych kompetencji ...

\section{Bibliografia}

Albin, Joanna. 2011. Kompetencja $z$ punktu widzenia ttumacza, [w:] Kompetencje tlumacza. Tom dedykowany Profesor dr hab. Elżbiecie Tabakowskiej, M. Piotrowska i inni (red.), s. 39-44. Kraków: Krakowskie Towarzystwo Popularyzowania Wiedzy o Komunikacji Językowej „Tertium”.

Bartoszewicz, Iwona, Małgorzewicz, Anna. 2013. Studia Translatorica 4. Kompetenzen des Translators. Theorie-Praxis-Didaktik 4. Wrocław, Dresden: Neisse Verlag.

Biel, Łucja. 2011. Kompetencja w zakresie świadczenia ustug thumaczeniowych a uczenie się przez projekt, [w:] Kompetencje ttumacza. Tom dedykowany Profesor dr hab. Elżbiecie Tabakowskiej, M. Piotrowska i inni (red.), s. 97-99. Kraków: Krakowskie Towarzystwo Popularyzowania Wiedzy o Komunikacji Językowej „Tertium”.

Dybiec-Gajer, Joanna. 2013. Zmierzyć przektad? Z metodologii oceniania $w$ dydaktyce przekładu pisemnego. Kraków: Universitas.

Kelly, Dorothy. 2005. A Handbook for Translator Trainers. Manchester.

Kiraly, Donald. 2000. A Social Constructivist Approach to Translator Education. Empowerment from Theory to Practice. Manchester.

Kościałkowska-Okońska, Ewa. 2013. Dydaktyka przekładu tekstów specjalistycznych $w$ kontekście rozwoju kompetencji tlumaczeniowej, [w:] Rocznik Przekładoznawczy, nr 8/2013, s. 137-151. Torun: Wydawnictwo Naukowe Uniwersytetu Mikołaja Kopernika.

Kubacki, Artur Dariusz. 2013. Zur forensischen Kompetenz eines vereidigten Translators. [w:] Studia Translatorica 4. Kompetenzen des Translators. Theorie-Praxis-Didaktik 4. I. Bartoszewicz, A. Małgorzewicz (red.). s. 69-83. Wrocław, Dresden: Neisse Verlag.

Małgorzewicz, Anna. 2014. Językowe i niejęzykowe kompetencje tlumacza. Próba zdefiniowania celów translodydaktyki akadmickiej. [w:] Lingwistyka Stosowana/Applied Linguistics/ Angewandte Linguistik, nr 11/2014, s. 1-10. Warszawa: Uniwersytet Warszawski, Instytut Komunikacji Specjalistycznej i Interkulturowej.

Piotrowska, Maria i inni. 2012. Kompetencje tlumacza. Tom dedykowany Profesor $d r$ hab. Elżbiecie Tabakowskiej. Kraków: Krakowskie Towarzystwo Popularyzowania Wiedzy o Komunikacji Językowej „Tertium”. 